JURNAL EKONOMIKA

https://journal.uwgm.ac.id/index.php/ekonomika/index

2580-8117 E-ISSN, 2527-6379 P-ISSN

Juni 2018, Vol.7 No.1

\title{
EFEKTIVITAS PELAKSANAAN UNDANG-UNDANG TAX AMNESTY DI WILAYAH KANTOR PELAYANAN PAJAK PRATAMA BONTANG KALIMANTAN TIMUR
}

\author{
Iskandarsyah Satriya ${ }^{1}$ \\ iskandarsyahsatriya@gmail.com \\ Elsika Suci Ramadhani ${ }^{2}$ \\ elsikasuciramadhani@gmail.com
}

\author{
${ }^{1}$ Dosen Fakultas Ekonomi Program Studi Akuntansi UWGM Samarinda \\ ${ }^{2}$ Mahasiswa Fakultas Ekonomi Program Studi Akuntansi UWGM Samarinda
}

\begin{abstract}
ABSTRAK
Tujuan dari penelitian ini adalah untuk mengetahui tingkat penerapan efektifitas tax amnesty terhadap penerimaan pajak pada Kantor Pelayanan Pajak Bontang Pratama pada periode pertama Juli satu, 2016 hingga September tiga puluh satu 2016, periode kedua Oktober satu 2016 hingga Desember tigapuluh satu 2016 dan periode ketiga Januari yang 2017 hingga Maret tiga puluh satu 2017.

Data dianalisis dengan metode deskriptif dalam menggambarkan prosedur Pengampunan Pajak. Analisis kualitatif digunakan untuk menunjukkan tingkat implementasi efektifitas Pengampunan Pajak. Hasil penelitian menunjukkan bahwa tingkat penerapan efektivitas Pengampunan Pajak pada tahun 2016 sebesar 79,10\% dan peningkatan terjadi pada tahun 2017 sebesar 88,69\%, yang dikatakan memadai.

Kata kunci : Kebijakan Pengampunan Pajak, Efektivitas, Penerimaan Pajak
\end{abstract}

\section{ABSTRACT}

The purpose of this study is to determine the implementation level of effectiveness of Tax amnesty toward the tax revenue at the Bontang Pratama Tax Service Office in the first period of July the one, 2016 until September the thirty one 2016, second period of October the one 2016 until December the thirty one 2016 and the third period of January the one 2017 until March thirty one 2017.

The data was analyzed by descriptive method in describing the Tax Amnesty procedure. The qualitative analysis was used to show the implementation level of effectiveness of Tax Amnesty. The results showed that the implementation level of the effectiveness of Tax Amnesty in 2016 of 79,10\% and increase occurred in the 2017 of $88,69 \%$, that it is said to be adequate.

Keyword: Tax Amnesty Policy, Effectiveness, Tax Receipts 
JURNAL EKONOMIKA

https://journal.uwgm.ac.id/index.php/ekonomika/index

2580-8117 E-ISSN, 2527-6379 P-ISSN

Juni 2018, Vol.7 No.1

\section{Pendahuluan}

\section{Latar Belakang}

Penerimaan kas Negara dari sektor pajak merupakan peran penting terhadap kelangsungan sistem perekonomian di suatu Negara. Pajak merupakan kontribusi wajib dari masyarakat yang bersifat memaksa tanpa harus mendapatkan imbalan secara langsung yang dikelola oleh Direktorat Jenderal Pajak (DJP). Pajak yang nantinya dipungut oleh pemerintah akan digunakan untuk kelangsungan hidup Negara dan sebagai sumber pembiayaan Negara (APBN) untuk menjalankan roda pemerintahan.

Sasaran utama dari kebijakan keuangan Negara di bidang penerimaan dalam negeri adalah untuk menggali, mendorong, dan mengembangkan sumber-sumber penerimaan dari dalam negeri agar jumlahnya meningkat sesuai dengan kebutuhan pembangunan. Dari data yang didapatkan Badan Pusat Statistik tingkat ekspor Indoneia sektor industri pengelolaan 2017 mencapai US\$ 153,90 miliar meningkat 17,16 persen di banding periode yang sama tahun 2016, lebih besar dibandingkan tahun 2014 di mana tingkat ekspor industri pengelolaan mencapai US\$ 119.753 miliar. Sedangkan tingkat impor tahun 2015 mencapai US\$ 109.515 mengalami penurunan menjadi US\$ 108.240 miliar tahun 2016. Hal ini menjadi salah satu indikator bahwa tingkat pertumbuhan industri di Indonesia mengalami perbaikan setelah penurunan yang cukup signifikan yang terjadi di tahun 2015. Peningkatan populasi usaha ini seharusnya diikuti dengan meningkatnya penerimaan pemerintah dari sektor pajak. Karena itu kebijakan sektor perpajakan harus terus diamati pergerakannya dan diarahkan untuk memperbaiki perekonomian serta pembangunan yang ada di Indonesia.

Dalam sistem pemungutan pajak Indonesia menganut sistem self assessment dimana wajib pajak diberikan hak untuk menghitung, membayar serta melaporkan sendiri kewajiban perpajakannya. Sistem self assessment diatur dalam pasal 12 Undang-undang Ketentuan Umum Perpajakan. Sistem penerapan pemungutan pajak seperti ini memiliki keuntungan di mana kantor pajak tidak akan disulitkan dalam menghitung dan mendata jumlah pajak yang seharusnya dibayar oleh wajib pajak. Tetapi, di sisi lain penerapan sistem ini seakan-akan memberikan kesempatan bagi wajib pajak, untuk mengurangi jumlah pajak yang harus dibayar dengan cara menekan beban pajak.

Secara historis, hingga saat ini pemerintah telah melakukan tiga kali perubahan atas Undang-undang Perpajakan atas Pengampunan Pajak atau Tax Amnesty yang ada sebelumnya (yaitu tahun 1964 dan 1984), sehingga perubahan Undang-undang atas pengampunan yang dilakukan pemerintah pada tahun 2016 tidak lain merupakan generasi ketiga dalam reformasi perpajakan Indonesia. Hal ini menunjukkan bahwa peraturan perpajakan Indonesia cukup akomodatif, dinamis, dan antisipatif dalam mengamati, mengkaji, dan menerapkan perkembangan yang 
JURNAL EKONOMIKA

https://journal.uwgm.ac.id/index.php/ekonomika/index

2580-8117 E-ISSN, 2527-6379 P-ISSN

Juni 2018, Vol.7 No.1

terjadi di luar perpajakan - seperti perkembangan ekonomi, moneter, industri, dan perdagangan, bahkan perkembangan sosial, politik, teknologi, dan sebagainyauntuk disesuaikan pengaturan perpajaknnya. Perkembangan apapun yang terjadi di luar perpajakan, selalu diantisipasi dan di proyeksikan peraturan pajaknya.

Dengan demikian, langkah perubahan yang dilakukan pemerintah terhadap Undangundang Tax Amnesty hingga tiga kali, bukanlah karena aturan yang ditetapkan dalam Undang-undang Perapajakan selalu salah atau tidak dapat dilaksanakan. Melainkan lebih diakibatkan oleh cepatnya terjadi perubahan-perubahan yang bahkan bersifat fundamental di berbagai aspek kehidupan, baik itu dalam bidang ekonomi, sosial, budaya, pertanahan, dan keamanan, maupun politik. Cepatnya perubahan ini ada yang secara bersama-sama dengan faktor internal di dalam negeri, demikian juga ada yang secara bersama-sama dengan faktor eksternal dari luar negeri, yang pada akhirnya mempengaruhi pengaturan perpajakan.

Menurut Undang-undang Republik Indonesia Nomor 11 Tahun 2016 pengampunan pajak (tax amnesty) diartikan sebagai berikut: Pengampunan pajak adalah penghapusan pajak yang seharusnya terutang, tidak dikenai sanksi administrasi perpajakan dan sanksi pidana di bidang perpajakan dengan cara mengungkap harta dan membayar uang tebusan sebagaimana diatur dalam Undangundang ini (Pasal 1).

Uang tebusan yang dimaksud adalah sejumlah uang yang dibayarkan wajib pajak ke Negara untuk mendapatkan pengampunan pajak. UU No. 11 Tahun 2016 menyebutkan pengampunan pajak dilaksanakan berdasarkan asas kepastian hukum; keadilan; kemanfaatan; dan kepentingan nasional. Pengampunan pajak dilaksanakan bertujuan untuk: (a) Mempercepat pertumbuhan dan restrukturisasi ekonomi pengalihan Harta, yang antara lain akan berdampak terhadap peningkatan likuiditas domestick, perbaikan nilai tukar Rupiah, penurunan suku bunga, dan peningkatan investasi; (b) Mendorong reformasi perpajakan menuju sistem perpajakan yang lebih berkeadilan serta perluasan basis data perpajakan yang lebih validm komprehensifn dan terintegerasi; dan (c) Meningkatkan penerimaan pajak, yang antara lain akan digunakan untuk pembiayaan pembangunan.

Besarnya uang tebusan dihitung dengan cara mengalikan tarif sebagaimana dimaksud dalam Pasal 4 Undang-undang Nomor 11 Tahun 2016 dengan dasar pengenaan uang tebusan. Dasar pengenaan uang tebusan dihitjg berdasarkan nilai harta bersih yang belum seluruhnya dilaporkan dalam SPT PPh Terakhir. Nilai harta bersih merupakan selisih antara nilai harta dikurangi nilai hutang, sedangkan untuk memperoldeh pengampunan pajak sebagaimana dimuat dalam pasal 8 Undang-undang Nomor 11 Tahun 2016 Wajib Pajak harus menyampaikan Surat Pernyataan kepada Menteri. Surat Pernyataan sebagiman ditandatangani oleh: Wajib Pajak orang pribadi: pemimpin tertinggi berdasarkan akta pendirian badan atau dokumen lain yang dipersamakan, bagi wajib pajak badan; atau penerima 
JURNAL EKONOMIKA

https://journal.uwgm.ac.id/index.php/ekonomika/index

2580-8117 E-ISSN, 2527-6379 P-ISSN

Juni 2018, Vol.7 No.1

kuasa; dalam hal pemimpin tertinggi berhalangan. Wajib pajak harus memenuhi persayaratan sebagai berikut:

a. Memiliki Nomor Pokok Wajib Pajak (NPWP);

b. Membayar uang tebusan;

c. Melunasi seluruh tunggakan pajak'

d. Melunasi pajak yang tidak atau kurang dibayar atau melunasi pajak yang seharusnya tidak dikembalikan bagai wajib pajak yang sedang dilakukan pemeriksaan bukti pemulaan dan/atau penyidikan;

e. Menyampaikan SPT PPh Terakhir bagi wajib pajak yang telah memiliki kewajiban menyampaikan Surat Pemberitahuan Tahunan Pajak Penghasilan; dan

f. Mencabut permohonan:

1. Pengembalian kelebihan pembayaran pajak;

2. Pengurangan atau penghapusan sanksi administrasi perpajakan dalam surat ketetapan pajak dan/atau surat tagihan pajak yang di dalamnya terdapat pokok pajak yang terutang;

3. Pengurangan atau pembatalan ketetapan pajak yang tidak benar;

4. Keberatan;

5. Pembetulan atas surat ketetapan pajak dan surat keputusan;

6. Banding;

7. Gugatan; dan/atau

8. Peninjauan kembali

Dalam hal wajib pajak sedang mengajukan permohonan dan belum menerbitkan surat keputusan atau putusan. Uang tebusan harus dibayar lunas ke kas Negara melalui Bank Persepsi. Pembayaran uang tebusan menggunakan surat setoran pajak yang berfungsi sebagai bukti pembayaran uang tebusan setelah mendapatkan validasi.

Hingga semua persayaratan dipahami dan dilengkapi oleh wajib pajak pengajuan Tax Amnesty sudah dapat dilakukan dengan datang ke Kantor Pelayanan Pajak tempat wajib pajak terdaftar dengan membawa surat pernyataan. Kantor Pelayanan Pajak tempat wajib pajak terdaftar ialah tempat awal yang harus dituju untuk berkonsultasi dan diberi arahan mengenai pengisian dan pemenuhan kelangkapan dokumen yang harus dilampirkan dalam Surat Pernyataan.

Program Tax Amnesty ditujukan untuk seluruh lapisan masyarakat yang berlaku sejak disahkan sampai dengan tanggal 31 Maret 2017, yang mana dalam pelaksanaannya program ini dibagi menjadi tiga periode yakni Periode 1 dilaksanakan dari tanggal diundangkan sampai dengan tanggal 20 September 2016, dilanjutkan eriode II dari tanggal 1 Oktober 2016 sampai dengan tanggal 31 Desember 2016, dan Periode III dilaksanakan dari tanggal 1 Januari 2017 sampai dengan tanggal 31 Maret 2017. 
JURNAL EKONOMIKA

https://journal.uwgm.ac.id/index.php/ekonomika/index

2580-8117 E-ISSN, 2527-6379 P-ISSN

Juni 2018, Vol.7 No.1

Sejak diterapkan tanggal 28 Juli 2016 pemerintah mengharapkan agar penerapan Tax Amnesty bisa memperbaiki kondisi perekonomian Indonesia dari sektor pajak. Data Berita Dirjen Pajak Nasional pada tanggal 6 Desember, menyatakan bahwa tingkat partisipasi wajib pajak peserta amnesti pajak hingga di periode kedua masih rendah. Tax ratio yang masih rendah berpeluang meningkatkan penerimaan pajak pada periode ketiga pemberlakuan Tax Amnesty. Tingkat kepatuhan yang masih juga rendah mencerminkan kurangnya kesadaran wajib pajak dalam memenuhi kewajiban perpajakan.

Di Bontang sendiri, bila dilihat dari persentase penerimaan setiap tahunnya dapat dilihat dari Tahun 2015 realisasi penerimaan pajak di Kota Bontang sebelum dilakukan Tax Amnesty yaitu sebesar Rp3.106.814.018.391 dengan presentase 75.67\% dari target yang diharapkan oleh pemerintah. Sedangkan di Tahun berikutnya yaitu Tahun 2016 saat berlangsungnya program Tax Amnesty periode pertama (periode 1 Juli - 30 September 2016) hingga periode kedua (periode 1 Oktober - Desember 2016) presentase penerimaan pajak naik 78.69\% dari realisasi penerimaan pajak sebelum diberlakukan Tax Amnesty sebesar Rp3.143.550.583.057 dan realisasi penerimaan Tax Amnesty di Tahun 2016 sebesar Rp16.620.651.006 dengan presentase 0.42\%. Selanjutnya di Tahun 2017 di periode terakhir atau ketiga (periode 1 Januari - 1 Maret 2017) penerimaan pajak mengalami penurunan hingga $0.18 \%$ atau menjadi sebesar Rp6.564.855.200.

\section{Permasalahan}

Berdasarkan latar belakang yang telah dirumuskan maka, rumusan masalah sebagai berikut "Berapakah realisasi Tax Amnesty yang dilakukan di Kantor Pelayanan Pajak Pratama Bontang telah mencapai efektivitas?”

\section{Metode Analisis}

Efektivitas Tax Amnesty terhadap penerimaan pajak bisa dilihat dari perkembangan target serta realisasi pajak sebelum dan sesudah penerapan Tax Amnesty. Sehingga efektivitas pajak dapat dirumuskan sebagai berikut:

$$
\text { Efektivitas Tax Amnesty }=\frac{\text { Realisasi Penerimaan Tax Amnesty }}{\text { Target Penerimaan Tax Amnesty }} \times 100 \%
$$

Dalam hal ini, target penerimaan menjadi tolak ukur pencapaian usaha pemerintah Kota Bontang untuk mencapai hasil penerimaan Tax Amnesty yang diinginkan. Sedangkan untuk realisasi penerimaan berupa hasil yang telah dicapai. Hal ini menjadi jawaban yakni, apakah suatu target yang ingin dicapai sesuai dengan realisasi atau tidak sesuai, setelah Tax Amnesty selesai dilaksanakan. Dibawah ini penulis menggunakan data penerimaan pajak yang dimulai pada Tahun 2015 
JURNAL EKONOMIKA

https://journal.uwgm.ac.id/index.php/ekonomika/index

2580-8117 E-ISSN, 2527-6379 P-ISSN

Juni 2018, Vol.7 No.1

Tabel. Target dan Realisasi Penerimaan Pajak

di KPP Pratama Bontang

\begin{tabular}{|c|c|c|c|}
\hline \multirow{2}{*}{ Tahun } & \multirow{2}{*}{ Target } & \multicolumn{2}{|c|}{ Realiasi } \\
\cline { 3 - 4 } & & Nominal & Presentase \\
\hline 2015 & $4,105,751,001,000$ & $3,106,814,018,391$ & $75,67 \%$ \\
\hline 2016 & $3,995,019,378,000$ & $3,143,550,583,057$ & $78,69 \%$ \\
\hline 2017 & $3,639,805,568,000$ & $3,221,729,042,982$ & $88,51 \%$ \\
\hline
\end{tabular}

Sumber : KPP Pratama Bontang, data diolah.

\section{Pembahasan}

Penghitungan dibawah ini merupakan penjabaran atas tabel :.

1. Analisis penghitungan efektivitas penerimaan pajak saat dilaksanakan Tax Amnesty di KPP Pratama Bontang

a. Tahun 2015 (sebelum dilaksanakan Tax Amnesty)

$$
\text { Efektivitas }=\frac{3,106,814,018,391}{4.105 .751 .001 .000} \times 100 \%=75.67 \%
$$

b. Tahun 2016

Efektivitas $=\frac{3,143,550,583,057}{3.995 .019 .378 .000} \times 100 \%=78.69 \%$

c. Tahun 2017

$$
\text { Efektivitas }=\frac{3,221,729,042,982}{3.639 .805 .568 .000} \times 100 \%=88.51 \%
$$

Penghitungan diatas dapat disajikan sebagai berikut:

Tabel. Target dan Realisasi Penerimaan Tax Amnesty di Kantor Pelayanan

Pajak Pratama Bontang

\begin{tabular}{|c|c|c|c|l|}
\hline Tahun & $\begin{array}{c}\text { Realisasi Penerimaan } \\
\text { Tax Amnesty }\end{array}$ & $\begin{array}{c}\text { Target } \\
\text { Penerimaan Tax } \\
\text { Amnesty }\end{array}$ & $\begin{array}{c}\text { Presentase } \\
\text { Efektivitas }\end{array}$ & $\begin{array}{c}\text { Kriteria } \\
\text { Penilaian }\end{array}$ \\
\hline 2016 & $3,160,171,234,063$ & $3,995,019,378,000$ & $79,10 \%$ & $\begin{array}{l}\text { Kurang } \\
\text { Efektif }\end{array}$ \\
\hline 2017 & $3,228,293,898,182$ & $3,639.805,568,000$ & $88,69 \%$ & Cukup Efektif \\
\hline
\end{tabular}

Sumber : KPP Pratama, data diolah

Tabel Efektivitas Pelaksanaan Tax Amnesty Terhadap Penerimaan Pajak Per (Juni-Desember 2016) dan (Januari-Maret 2017)

\begin{tabular}{|c|c|c|c|c|}
\hline Tahun & Periode & $\begin{array}{c}\text { Target Penerimaan Tax } \\
\text { Amnesty }\end{array}$ & $\begin{array}{c}\text { Realisasi Penerimaan } \\
\text { Tax Amnesty }\end{array}$ & Presentase \\
\hline 2016 & I dan II & $3,995,019,378,000$ & $3,160,171,234,063$ & $79,10 \%$ \\
\hline
\end{tabular}


JURNAL EKONOMIKA

https://journal.uwgm.ac.id/index.php/ekonomika/index

2580-8117 E-ISSN, 2527-6379 P-ISSN

Juni 2018, Vol.7 No.1

2017

III $\quad 3,639,805,568,000$

$3,228,293,898,182$

$88,69 \%$

Tabel Efektivitas Pelaksanaan Tax Amnesty Terhadap Peneriman Pajak

Per (Juni-Desember 2016) dan (Januari-Maret 2017)

\begin{tabular}{|c|c|c|c|c|}
\hline Tahun & Periode & $\begin{array}{c}\text { Target Penerimaan } \\
\text { Pajak }\end{array}$ & $\begin{array}{c}\text { Realisasi Penerimaan } \\
\text { Pajak }\end{array}$ & Presentase \\
\hline 2016 & 1 dan II & $3,995,019,378,000$ & $3,143,550,583,057$ & $78,69 \%$ \\
\hline 2017 & III & $3,639,805,568,000$ & $3,221,729,042,982$ & $88,51 \%$ \\
\hline
\end{tabular}

Tabel Perbandingan Penerimaan Tax Amnesty Terhadap Penerimaan Pajak

\begin{tabular}{|c|c|r|}
\hline \multirow{2}{*}{ Tahun } & \multicolumn{2}{|c|}{ Selisih } \\
\cline { 2 - 3 } & Presentase & \multicolumn{1}{c|}{ Nominal } \\
\hline 2016 & 0,42 & $16,620,651,006$ \\
\hline 2017 & 0,18 & $6,564,855,200$ \\
\hline
\end{tabular}

Sumber: KPP Pratama Bontang, data diolah.

Berdasarkan penghitungan dan analisis diatas, maka penulis akan membahas hasil tersebut secara teoritis mengenai penghitungan Efektivitas Pelaksanaan Undang-undang Tax Amnesty diwilayah Kantor Pelayanan Pajak Pratama Bontang berdasarkan Undang-undang Nomor 11 Tahun 2016 dan Peraturan Menteri Keuangan 165/PMK.03/2017. Berikut uraian yang dapat penulis sampaikan:

Berdasarkan data diatas diperoleh keterangan sebagai berikut:

1. Pembahasan Target dan Realisasi Penerimaan Tax Amnesty

a. Pada pelaksanaan Tahun 2016 KPP Pratama Bontang menargetkan penerimaan Tax Amnesty dan penerimaan pajak sebesar Rp3,995,019,378,000 dengan persentase $79.10 \%$ dan realisasi penerimaan Tax Amnesty sebesar Rp3,160,171,234,063.

b. Sedangkan, di Tahun 2017 target penerimaan sebesar Rp3,639,805,568,000 dengan persentase $88.69 \%$. Bila dibandingkan dengan tahun sebelumnya penerimaan di tahun terakhir Tax Amnesty mengalami kenaikan yang cukup baik yakni, 0,18\% dari Tahun 2016. Kenaikan tersebut juga berpengaruh pada kenaikan realisasi penerimaan sebesar Rp3,228,293,898, 182.

2. Analisis tingkat efektivitas penerimaan Tax Amnesty

a. Dari tabel 5.2. diketahui bahwa tingkat efektivitas penerimaan Tax Amnesty Tahun 2016 adalah sebesar $79.10 \%$ dengan kriteria “Kurang Efektif'. Sedangkan, tingkat efektivitas Penerimaan Tax 
JURNAL EKONOMIKA

https://journal.uwgm.ac.id/index.php/ekonomika/index

2580-8117 E-ISSN, 2527-6379 P-ISSN

Juni 2018, Vol.7 No.1

Amnesty Tahun 2017 yaitu sebesar 88.69\% dengan kriteria "Cukup Efektif" walaupun pada periode akhir atau pelaksanaan Tahun terakhir tarif uang tebusan meningkat menjadi 5\% namun wajib pajak yang mengikuti program Tax Amnesty ikut meningkat. Hal ini juga dapat terjadi karena kesadaran dari wajib pajak itu sendiri untuk mengikuti program Pengampunan Pajak. Dari data analisis di tahun 2016 dan 2017 tersebut dapat disimpulkan jikalau program Pengampunan Pajak belum sepenuhnya dapat meningkatkan jumlah subjek dan objek pajak dalam jangka pendek dengan jumlah yang diharapkan memuaskan, banyak wajib pajak yang belum memiliki kesadaran akan mengikuti program tersebut.

b. Dalam mencapai tingkat efektivitas Penerimaan Tax Amnesty hingga dapat mencapai $100 \%$ atau sangat efektif. Pihak KPP Pratama Bontang dibawah naungan Direktorat Jenderal Pajak diwilayah Kalimantan Timur telah melakukan usaha-usaha dalam mempublikasikan program Tax Amnesty terhadap wajib pajak yang berada di daerah Bontang dan sekitarnya. Berikut beberapa jenis publikasi yang sudah diterapkan oleh pihak KPP Pratama Bontang adalah dalam bentuk Kampaye Simpatik, Workshop, Broadcast Short Massages Service, serta optimalisasi Helpdesk khusus pelaksanaan Tax Amnesty, juga pemasangan iklan diberbagai media massa. Selain itu, pihak KPP Pratama Bontang mengeluarkan Surat Himbauan kepada seluruh wajib pajak yang berpotensi untuk mengikuti Tax Amnesty.

3. Perbandingan penerimaan Tax Amnesty terhadap penerimaan pajak

a. Pada tabel 5.4. terdapat perbandingan penerimaan pada tahun 2016 dan 2017, di tahun 2016 dengan presentase 42\%, sehingga penerimaan Tax Amnesty menyumbang sebesar Rp16,620,651,006 terhadap penerimaan pajak.

b. Sedangkan di tahun 2017 , walaupun presentasenya hanya sebesar $18 \%$ dengan nominal sebesar Rp6,564,855,200 namun di tahun inilah cukup efektif penerimaan yang di dapatkan.

\section{Kesimpulan}

Berdasarkan hasil dan pembahasan yang telah dilakukan dalam pelaksanaan efektivitas penerimaan Tax Amnesty. Maka, dapat ditarik kesimpulan sebagai berikut:

1. Tingkat efektivitas Penerimaan Tax Amnesty pada Tahun 2016 adalah sebesar 78.69\% dengan kriteria "Kurang Efektif". Namun pada Tahun 2017 Penerimaan Tax Amnesty meningkat menjadi $88.51 \%$ namun belum mencapai efektif dengan 
JURNAL EKONOMIKA

https://journal.uwgm.ac.id/index.php/ekonomika/index

2580-8117 E-ISSN, 2527-6379 P-ISSN

Juni 2018, Vol.7 No.1

kriteria "Cukup Efektif" hal ini dirasa menjadi pencapaian karena peningkatan terjadi pada saat tarif uang tebusan naik menjadi $5 \%$.

2. Prosedur Pelayanan Tax Amnesty dan semua upaya untuk menarik jumlah wajib pajak untuk mengikuti Tax Amnesty telah sangat baik. 
JURNAL EKONOMIKA

https://journal.uwgm.ac.id/index.php/ekonomika/index

2580-8117 E-ISSN, 2527-6379 P-ISSN

Juni 2018, Vol.7 No.1

\section{DAFTAR PUSTAKA}

Agus, Budiatmanto 1999, Studi Evaluasi Kepatuhan Wajib Pajak Sebelum dan Sesudah Reformasi Perpajakan Tahun 1983, Tesis Program Pasca Sarjana Magister Akuntansi Universitas Gadjah Mada.

Andrian, Sutedi; 2011, Hukum Pajak, PT Raja Grafindo Persada. Jakarta.

Darise, Nurlan; 2006, Pengelolaan Keuangan Daerah, PT. Indeks Kelompok Gramedia Anggota IKAPI, Jakarta.

Herryanto, M., \& Toly, A. A; 2013, Pengaruh Kesadaran Wajib Pajak, Kegiatan Sosialisasi Perpajakan, Dan Pemeriksaan Pajak Terhadap Penerimaan Pajak Penghasilan di KPP Pratama Surabaya Sawahan. Tax and Accounting Review.

Laporan Hasil Penelitian, 2013, 1(1), 125-133.

Halim, Abdul; 2008, Akuntansi Sektor Publik; Akuntansi Keuangan Daerah Edisi 3, Jakarta, Salemba Empat.

Ulum, Ihyaul; 2009., Intellectual Capital: Konsep Dan kajian Empiris, Yogyakarta: Graha Ilmu.

Mardiasmo; 2009. Perpajakan Indonesia, Edisi Revisi. Andi. Yogyakarta.

2016. Perpajakan, Edisi Revisi. Penerbit Andi, Yogyakarta.

2012 Perpajakan, Edisi Revisi 2012. Andi. Yogyakarta.

Kuncoro, Mudrajad; 2013. Metode Riset untuk Bisnis dan Ekonomi. Edisi 4. Jakarta: Erlangga.

Mulyono, Djoko; 2014. Akuntansi Pajak, Jakarta: Salemba Empat.

Pujoalwanto, Basuki 2014. Perekonomian Indonesia. Penerbit Graha Ilmu. Yogyakarta.

Rifqiansyah, Hasbi, Muhammad Saifi, Devi Farah Azizah. 2014. Analis Efektivitas dan Kontribusi Penagihan Pajak Aktif Terhadap Pencairan Tunggakan Pajak. Jurnal, 2014, Universitas Brawijaya, Malang

Saidi, Djafar, Muhammad, 2007. Pembaruan Hukum Pajak. PT Raja Grafindo Persada, Jakarta

Sugiyono. 2015. Metode Penelitian Pendidikan (Pendekatan Kuantitatif, Kualitatif dan $R \& D$ ). Penerbit CV. Alfabeta. Bandung. 
JURNAL EKONOMIKA

https://journal.uwgm.ac.id/index.php/ekonomika/index

2580-8117 E-ISSN, 2527-6379 P-ISSN

Juni 2018, Vol.7 No.1

Triantoro, A. 2007. Efektifitas Pemungutan Pajak Reklame dan Kontribusinya terhadap Penerimaan Pajak Daerah di Kota Bandung, 1-24.

Wirenungan, O. L, 2013. Sosialisasi Perpajakan, Pelayanan Fiskus dan Sanksi Perpajakan terhadap Kepatuhan WPOP di KPP Manado dan KPP Bitung.

Jurnal, 2013, EMBA, 1(3), 960-970. http://doi.org/ISSN 2303-1174

Website:

www.pajak.go.id

https://www.antaranews.com/berita/667582/peraturan-menteri-keuangan-165-

tingkatkan-kepatuhan-wajib-pajak 